\title{
Peace Building in Colombia. Regional Impacts on Security of the National Policy for Territorial Consolidation and Reconstruction
}

\section{By Briggitte Andrea Aguirre Munoz}

Abstract- This study evaluates the effects of the National Policy for Territorial Consolidation and Reconstruction (PNCRT) on security in the regions affected by the armed conflict. It focused on analysing its effect on life threats, infrastructure damage and the spread of illicit crops through a combination of statistical techniques called Propensity Score Matching and Difference in Differences. Its premise is based on the idea that the execution of the policy of peace and institutional strengthening would significantly improve security conditions. Indeed, results indicate that the PNCRT has succeeded in improving various security indicators in the regions where it was implemented, except the eradication of illicit crops.

Keywords: colombia; internal armed conflict; security, peace agreements, propensity score matching.

GJMBR-G Classification: JEL Code: C13, D74, H1, N4, O17, 018

Strictly as per the compliance and regulations of:

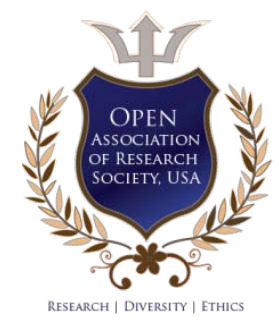

(c) 2020. Briggitte Andrea Aguirre Munoz. This is a research/review paper, distributed under the terms of the Creative Commons Attribution-Noncommercial 3.0 Unported License http://creativecommons.org/licenses/by-nc/3.0/), permitting all non-commercial use, distribution, and reproduction in any medium, provided the original work is properly cited. 


\title{
Peace Building in Colombia. Regional Impacts on Security of the National Policy for Territorial Consolidation and Reconstruction
}

\author{
Briggitte Andrea Aguirre Munoz
}

\begin{abstract}
This study evaluates the effects of the National Policy for Territorial Consolidation and Reconstruction (PNCRT) on security in the regions affected by the armed conflict. It focused on analysing its effect on life threats, infrastructure damage and the spread of illicit crops through a combination of statistical techniques called Propensity Score Matching and Difference in Differences. Its premise is based on the idea that the execution of the policy of peace and institutional strengthening would significantly improve security conditions. Indeed, results indicate that the PNCRT has succeeded in improving various security indicators in the regions where it was implemented, except the eradication of illicit crops.
\end{abstract}

Keywords: colombia; internal armed conflict; security, peace agreements, propensity score matching.

\section{INTRODUCTION}

C olombia is a very diverse country in terms of climate, geography, institutions and culture. Besides, it's a country that has been built from specific realities at the regional level (Chernick, 1999). The way the territory was both settled and politically consolidated since the colony period does not allow any generalisation at any level. In the words of Geertz, "The state-nation in Colombia has been "a social instrument made to respond to unequal identities, unclear wishes and acknowledgements that compete among themselves". (Geertz, taken from González pp. 25). Colombia is a country of regions (González, Bolívar, and Vásquez 2003)

Several rigorous studies agree that one of the main causes of persisting armed conflict in a country is the concept of a weak or failed state, or even a nonexistent one (Jackson, Quasi-States; Bayart, State in Africa; Zartman, Collapsed States Besley and Torsten, State Capacity, Acemoglu, Ticchi, Vindigni, Emergence States). The Colombian state has indeed an uneven government presence in all regions; unfortunately, this has provided an opening for insurgent groups to be "able to resist the central government's attempts to supposed modernization", to control local areas neglected by government institutions and to disconnect them from national markets (González, 2014) and the provision of security (Bulla y Guarín, 2015). There is no doubt that due to decades of systematic internal conflict and to the evolution of armed opponents at the local Author: e-mail: briggitte.aguirre@uniagustiniana.edu.co level, the Colombian state has been sharing his governance in a coacted, parallel or contested way (Duarte, 2016, González, 2014, Bates, 2001).

Indeed, González (2014) pointed out that the main cause of the internal armed conflict in Colombia for more than five decades together with its devastating effects in terms of human lives and damage to economical infrastructure is the consequence of an uneven presence of the state in all regions. With in this context, Duarte (2016) also claimed that the unev en presence of the Colombian state is associated with the concentration of power in each region. There fore, the state governance capacity or its absence in some regions versus armed opponents, that have limited their governance in a contested way, would be the main cause of the conflict. To this point, Duarte acknowledges the existence of a state that has adapted itself to each region or even the existence of a parallel state in different areas of Colombia.

Alves (2000) and Jackson (1990) state that the conflict can not be perpetuated where there is a weak presence of the state, which is a statement that goes together with what some authors have defined as a failed state. (Acemoglu, Ticchi, Vindigni, 2011); In any case, it has been pointed out that Colombia is a state that has gone through an ongoing consolidation process; a poor state that has been incapable of imposing itself and facing insurgent groups that submit the territory.

Yet, in this regard, some authors share different opinions. Some of them ensure that the unequal presence of the state in regions is due to the convenience of the government in power that pursue economical benefits and take advantage of the lack of regulation and solid institutions; in this case, the state would act as an accomplice. (Barham y Kleinfield, 2018). Evidence of this is seen in the way self-defence groups became paramilitary groups in some regions of the country; in addition to challenging the guerrillas, to decrease land prices for their benefit, they used violence against civilians, which was endorsed by the military (Barham and Kleinfield, 2018).

Whether they were weak, complicit, or still developing, it is safe to say that the various Colombian governments have never had complete control of the country, which created 'possibility conditions'i for 
various opponents of the government to reorganize, exercise local authority, and create conflict in these regions

Given that state-building depends on peacekeeping (Böge, at al., 2008), it becomes urgent to provide the most affected regions with the proper tools. For this reason, various administrations have negotiated peace agreements with different armed groups at different times during the conflict. Also, they have implemented plans and policies to strengthen state institutions in the regions (López, 2016). In fact, it must be recognized that state capacity has improved in recent decades and, although little, the legitimacy of government institutions has gained space in the territories. (BarreraOsorio, Maldonado, and Rodríguez 2012).

Despite the above, in Colombia, different groups have made the bet of consolidating the state institutions in the regions of conflict; indeed, they have worked for the pacification of the territory together with the re-establishment of security and its eventual economical and social ascent. To this respect, López (2016) notes that there have been at least ten peace plans in Colombia that started during the term of expresident Lleras, (1958-1962) and recently drove to the peace agreement with guerillas of the Revolutionary Armed Forces of Colombia, FARC-EP in 2016, during the term of ex-president Santos.

In this framework, this research contributes to the literature of state-building by evaluating the impact of the interventions carried out by the National Policy for territorial consolidation and reconstruction (PNCRT) implemented in conflict regions during the term of Juan Manuel Santos (2010-2014). This policy brought together more than 30 years of government effort through trial and error to establish peace in the regions. It happened at a critical time of internal conflict while negotiations with the guerrillas of the Revolutionary Armed Forces of Colombia - People's Army (Fuerzas Armadas Revolucionarias- Ejercito del Pueblo - FARC$E P$ ) and the National Liberation Army (Ejército de Liberación Nacional - ELN) were taking place. Finally, as it was said, the negotiations with FARC-EP reached a successful conclusion in 2016.

It is worth clarifying that this study relies on a definition of the role of the state which legitimises it. (Mann, 1993); that is both, the power to use violence and the possibility of collecting taxes (known as imperium). This is the basis for studying the fundamental goal of the PNCRT, in other words, the capacity of rebuilding the regions devastated by decades of violence. Of course, this presumes that establishing peace around the regions in conflict is one of basic preconditions to legitimize the power of the State, specifically with regard to the use of force. Indeed, it is expected that the implementation of a peace policy will ensure progress by making the country safe and enabling citizens to exercise their civil and economic rights.

Statistical tools such as Propensity Score Matching and the Difference in differences were applied for this study. The former was used to match municipalities that were treated by the Policy with others that shared identical observable characteristics, but which were not treated by the policy. Once the matching of municipalities was achieved, the effects of the policy were compared with the latter, the Difference in Differences technique. Of course, this involved an analysis that took geographical and socioeconomic differences into account.

Thus, this paper not only provided data on how the PNCRT succeeded in re-building peace in regions but also, unlike the existing literature in this area, it brought evidence of the rebuilding of institutional capacity in the regions where conflict has predominated

Last, the remainder of this paper focuses on explaining what the PNCRT is, its origins and its main background. It also describes how this policy was implemented, highlighting the importance of its geographical focus, which constituted the major challenge for its evaluation and justified the use of two econometric techniques. Results are classified in three main areas according to the PNCRT objectives in terms of peace building, mitigating threats to human life and survival, attacks on public and private infrastructure, and the eradication of illicit crops. Lastly, conclusions emphasize both the importance of PNCRT and some remaining issues as a basis for further research.

\section{Recent Background to the National POlicy For Territorial CONSOldDATION} AND Reconstruction

\section{a) From Plan Colombia to the Consolidation Policy}

Prior to the PNCRT, the Plan Colombia program stood for peace, prosperity and the state strengthening. It started during the term of ex-president Pastrana (1998-2002) and it was incorporated into the Democratic Security Policy during the two terms of ex-president Uribe. Since it was sponsored by the international community, the military force not only increased but was modernised as an offensive strategy against guerrillas. This way, the state presence in the regions evidenced both in the defence policy and in democratic security.

Initially, Plan Colombia prioritized the solving of the armed conflict. Thus, the dialogue with guerilla groups was meant to be the basis of the program. Unfortunately, it didn't succeed because none of the parts showed a real willingness to build peace during the Caguan negotiation in 1999. In fact, while the state carried out the consolidation of counter-insurgency strategies with the help of Comando Sur in the state of Florida, guerrillas took advantage of the demilitarized 
zone to strengthen their criminal conduct and their militia army.

It's important to note that president Pastrana policy left behind other urgent problems such as an increase in the guerrillas purchasing power emerging from the access of drug trafficking. For this reason, when Alvaro Uribe took office, he highlighted the harmful consequences of illegal drugs that threatened the country's economy and democracy. Indeed, during his two terms, president Uribe focused on two pillars: both, illegal crops and counter-insurgency war.

During the second Uribe term, the Comprehensive Action Doctrine (Doctrina de Acción Integral - DAl) was enacted and subsequently led by the Centre for Coordination and Comprehensive Action (Centro de Coordinación y Acción Integral - CCAl). This doctrine was designed by Juan Manuel Santos, who was the Minister of Defense at the time. The CCAI was composed of fourteen governmental entities that sought to strengthen the regions that the state gradually recovered by military action.

The Comprehensive Consolidation Program (Programa de Consolidacion Integral (PCI)) was designed based on the DAl, in 2017 and maintained both, the counter-narcotics and the counter-insurgency character of CCAl. Besides, it had a team on its own and included a regional structure that integrated the regions into national markets.

In 2009, the PCl was integrated into the National Consolidation and Reconstruction Policy. By the end of 2011, ex-president Juan Manuel Santos created the Special Administrative Unit for Territorial Consolidation (UACT) for the purpose to prevent any reversal of the improvements of public security forces in terms of security.

\section{b) The National Policy for territorial Consolidation and Reconstruction}

The National Policy for Consolidation and Territorial Reconstruction PNCRT came about during the administration of ex-president Santos and was led by the National Security Council. To implement the PNCRT, decree 4161 dated November 3 of 2011, created the Special Administrative Unit for Territorial Consolidation (UACT). This was a legal entity with its assets, national scope, administrative and financial autonomy, that was attached to the Administrative Department for Social Prosperity (Departamento Administrativo para la Prósperidad Social), the government entity that leads the Sector of social inclusion and reconciliation.

The UACT is part of this sector, along with the Colombian Family Welfare Institute (Instituto Colombiano de Bienestar Familiar - ICBF), the Unit for the Victims Assistance and Reparation (Unidad para Atención y Reparación a las Victimas), the National Agency to Eliminate Extreme Poverty (Agencia Nacional para la Superación de la Pobreza Extrema) and the National
Centre for Historical Memory (Centro Nacional de Memoria Histórica)".

All the previous efforts that the Colombian State had undertaken to consolidate its presence along the national territory were pursued by the PNCRT. Its reason for being was to establish the institutional and legal control over Colombia's regions; to guarantee the protection of citizens exercising their rights as well as to ensure citizen participation and achieve the economical, social and institutional integration of the targeted regions by creating conditions to sustain secure living conditions.

In terms of the conceptual framework of PNCRT, it relies on three major bases consisting of the counterinsurgency doctrine (COIN), anti-drugs policies from Plan Colombia and a regional and social development component of the areas where it was implemented. The COIN is a political and military theory built up to help the state facing an asymmetric war against the insurgency that affects both, political and social order.

It's important to note that the PNCRT focused on solving the weak presence of the state in areas that were marginalised by violence. Its main challenge was to maintain security in recovered zones ensuring the irreversibility of the public force improvements in terms of securityiii; that would be done by establishing institutions that would pay off debts concerning developmental, institutional, economical and social prosperity at the local level.

\section{Strategy for Evaluating the Nationalpolicy FOr TERRITORIAL Consolidation and Reconstruction}

Once the policy was defined, to implement it, the government needed to define the municipalities where it would startup. These regions were called " Treatment municipalities ». It was also necessary to find out other districts that shared the same characteristics, called the "Control municipalities ", whose comparison with the prior would measure the impact of the policy. Last, data was built after defining a design to measure outcome variables and a period to study the impact of the policy.

\section{a) Criteria for the selection of the regions}

To evaluate the impact of PNCRT, this study uses the intervention regions "Treatment regions " selected by the policy ${ }^{i v}$. According to the presidency, the PNCRT selected areas where illicit economical activity, public disturbance, precarious rural living conditions and illegal territory control by armed groups seemed to prevail.

As we can see in table 1 , the areas were grouped into three major zones of analysis; the northeast zone, that covers the regions of Catatumbo 
and Arauca; a northwest region that covers the Nudo de Paramillo and Montes de María region and a large southwest region that encompasses territories from the department of Nariño to the department of Meta. Table 1. Zones according to the PNCRT criteria.

Table 1: Zones defined by the PNCRT- Regions grouped for regional analysis

\begin{tabular}{|c|c|c|}
\hline Zone 1 & Zone 2 & Zone 3 \\
\hline Northeast Region & Northwest Region & Southwest Region \\
\hline Catatumbo & Montes de Maria & Central Mountain Range \\
\hline Arauca & Nudo de Paramillo & Cauca \\
\hline \multirow{3}{*}{} & & Tumaco \\
\cline { 3 - 3 } & & Macarena \\
\cline { 3 - 3 } & & Caguan River \\
\cline { 3 - 3 } & & Putumayo \\
\hline
\end{tabular}

Source: created by the author

For clarity, Figure 1 shows the precise location on the map of Colombia of the 59 municipalities that were selected to be intervened by the PNCRT and on which its impacts were estimated. These municipalities, as indicated in the table above, were grouped into three analysis zones, which are delimited in circles. It is worth reiterating that, for this study, the definition of the treatment regions, selected by the PNCRT, where the internal conflict prevailed, was taken into account.

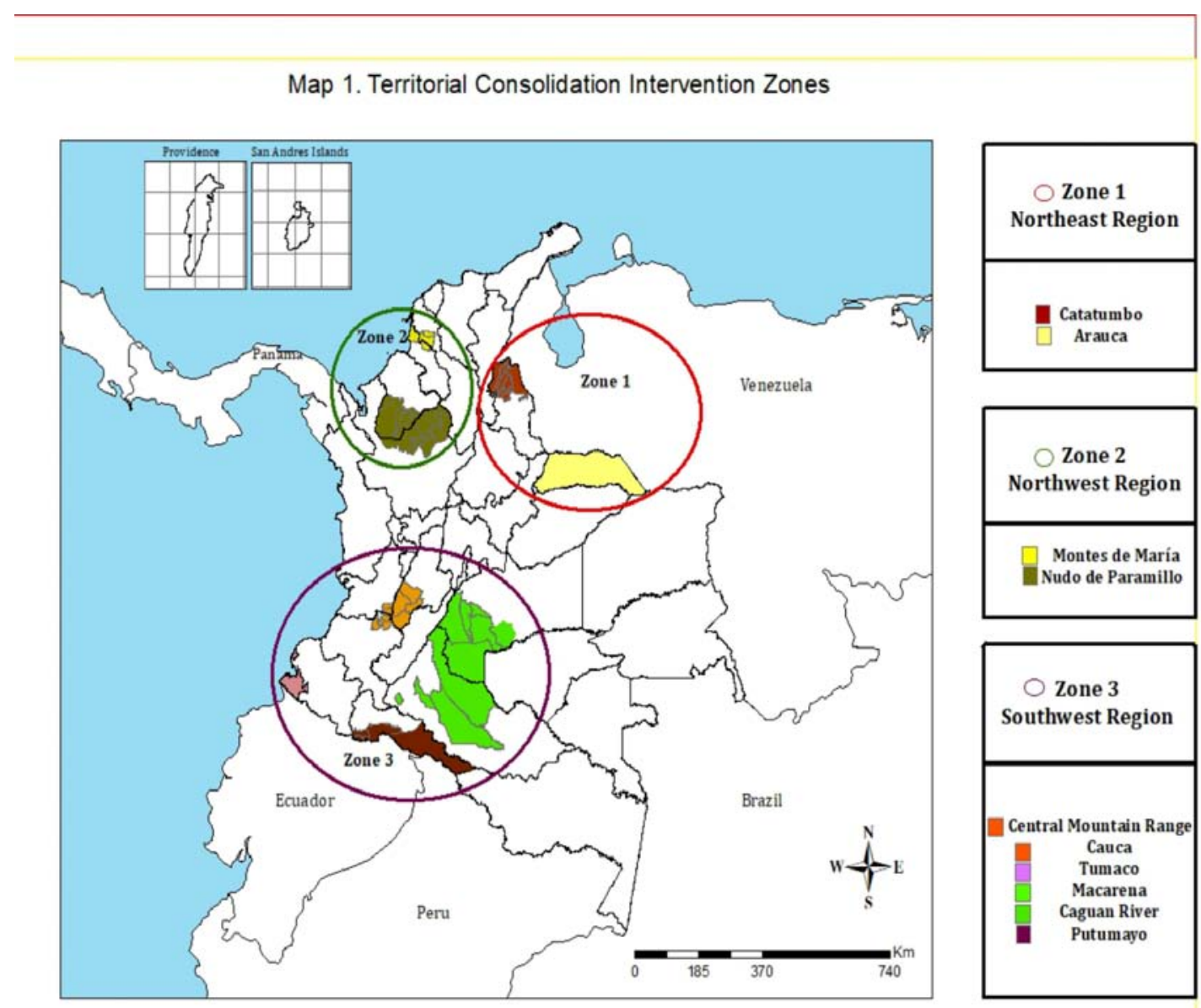

Figure 1: Map-PNCRT Intervention Zones

Source: created by the author

As defined by the Office of the President of the Republic, the PNCRT focuses on areas with regional imbalances, repeated disturbances of public order, territorial control by illegal armed groups, illicit economic activities, and precarious living conditions for rural populations ${ }^{v}$. 
Furthermore, the policy's criteria for selecting the regions correspond to the various strategies arising from illegal activities. The impacts of the conflict reveal the way armed groups used these areas as corridors for drugs and weapons, rear-guard or protected areas, or areas rich in extractive minerals and an evolution concerning their strategies (Salas-Salazar, 2016)

The methodology for assessing the policy's impact has four components:

- Select the evaluation period and identify the treatment municipalities in the regions of internal armed conflict

\section{Develop Database}

- Identify municipalities for the comparison and estimation strategy

- $\quad$ Find measures for outcome variables

b) Selection of the evaluation period

To assess the impact of PNCRT, it was necessary to set up a period before the intervention and a follow-up period (after it). This way, a baseline was defined from 2010, the year in which the intervention was planned but not yet implemented, and the year 2015 (period of evaluation of the impact, for postintervention comparisons). This way, it was possible to have a suitable time to evidence the effects of the policy. Similarly, a fundamental component of the information required is the identification of the regions for the comparison (control regions), which will be explained in detail.

Finally, it should be noted that both, longitudinal information and the contrast between the outcome variable trends before and after the implementation of the policy, made the comparison between «control regions » and « treatment regions » possible.

\section{c) Database construction}

Three types of data constitute the analysing variables of this study. They were collected to characterise the districts where the policy would be implemented. For this purpose, data related to their social-economic conditions as well as armed conflict and the expansion of illicit crops and drug trafficking in those districts were collected. Nonetheless, to determine the impact of PNCRT, this study only focused on the data related to the armed conflict which eventually would give an account of improvement and security maintenance in each district.

To determine the internal armed conflict behaviour, two sources were consulted; on the one hand, the Unity of Attention and Integral reparation of victims, UARIV, which provided data about internal forced displacement; on the other hand, the observatory of the National Center of Historical Memory (CNMH) whose data was based on the internal armed conflict between 1985 and 2015.
According to PNCRT, data about drug war should also be taken into account to consolidate security in the districts. The Integrated Illicit Crops Monitoring System (Sistema Integrado de Monitoreo de Cultivos llícitos -SIMCl) which is part of the United Nations office on drugs and Crime provided information on this issue. For this case, a Dummy variable was developed, in which a one (1) was assigned to the districts where there are illicit farming and zero (0) where there is not.

Lastly, concerning socio-economic conditions of each district, the National Administrative Department of Statistics (Departamento Administrativo Nacional de Estadística - DANE) provided information about urban and rural population figures since 1985, linear distance to departmental and national capitals, municipality area, municipality altitude, and Unmet Basic Needs (Necesidades Básicas Insatisfechas - NBI).

\section{d) Identification of municipalities for the comparison}

\section{i. Control districts}

To assess the effect of a program intervention requires to know the difference between the result variable for an individual that has been impacted and the result variable for the same individual if the policy had not existed. The first condition is known since the information exists and the data are available; however, the second, which is a hypothetical condition, cannot be observed because data are not available; this is known as the 'counterfactual' conditional. Yet, to build it, regarding the choice of municipalities and for comparison and control purposes, it was necessary to find out districts that shared the same characteristics as «Treatment districts» in terms of socio-economic, demographic and conflict situation and that could have also been selected by the PNCRT.

\section{ii. The estimation or matching Method}

The statistical matching technique called Propensity Score Matching (PSM) was implemented to find out the "counterfactual», these municipalities or clones that had the same probability of being covered by the policy.

The objective of this methodology is to identify and weight the characteristics that make the probability distribution of the two samples similar in terms of the observable characteristics of treatment and control groups that determined that led them be part of the intervention programme.

The Propensity Score (PS) or participation probability, corresponds to a numerical value between zero and one for each individual that was analysed (districts that were intervened and those that were not). it represents the probability of having been selected for the program according to each one of the observed characteristics of individuals (Municipalities). 
Districts were matched according to their estimated probability of being covered, given their observable characteristics. $P(x)$. i.e, those treatment and control municipalities with very similar coverage probabilities. This probability of coverage is defined as:

$$
\mathrm{P}(\mathrm{X})=\mathrm{P}(\mathrm{D}=1 \mid \mathrm{X})
$$

where $P(D=1 \mid X)$ is the probability of participating in the intervention programme given a set of observable characteristics $^{\mathrm{vi}}$.

Assuming that any selection bias is only due to differences in observable characteristics, the calculation of the program's impact could be estimated in a nonbiased manner, as it is showed by the difference in the average value of the outcome variables of both kinds of districts. The assumptions needed to determine the programme's effects are first, conditional independence (that is, unobservable factors that do not affect participation), and second, considerable overlap in PSs between the participating (treatment or

$$
\tau_{P S M}^{A T T}=E_{P(X) \mid D=1}\{E[Y(1) \mid D=1, P(X)]-\{E[Y(0) \mid D=0, P(X)]
$$

According to Bernal and Peña (2011, 2017), $E_{P(X) \mid D=1}$ is the estimated value concerning the probability of having been chosen $P(X)$; $\{E[Y(1) \mid D=1, P(X)]$ is the expected value of the observable variables within the group that was covered by the PNCRT; $\{E[Y(0) \mid D=1, P(X)]$ is the contra factual, which corresponds to the expected value of observable variables within the group where the PNCRT was implemented, in the hypothetical case they wouldn't have been intervened. The PSM estimator is the average difference between the municipalities that were covered by the PNCRT and the control municipalities of SP; it is pondered by the participation probability (PS).

On the other hand, the Simple Average Nearest Neighbour Estimator method was used, both, with and without replacement (Khandker et al., 2010). This estimator allows each treated municipality to be compared with one that has the mathematically nearest probability of having been chosen, but that was not covered by the PNCRT. Subsequently, the probability differences between each treated and untreated municipality are calculated to form a vector of distances that must be ranked from smallest to largest. Next, the value of the analysed variable for each municipality must be compared with the $\mathrm{N}$ municipalities with the nearest probabilities in the control group. This work used one (1) nearest neighbour (the PS was also reviewed with three and four municipalities) to find the ATT, which is given by:

$$
A T T=\sum_{K=1}^{N} \frac{\left(X_{k-} X_{m, k}\right)}{N_{t}}
$$

$\mathrm{Nt}$ is the total number of municipalities targeted by the policy; the ATT value then equals the exact effect intervened) and non-participating (control) municipalities (Caliendo, 2008; Bernal, 2011).

Both, subject to intervention and not subject to intervention distributions can be obtained by finding a PS for each municipality. There will be an area where these two distributions overlap. Observations that are not within this area of overlap should be removed from the sample to be used. This overlap area is also called the common support area (SP), and any observations of treatment municipalities with PSs greater than the maximum PS for control municipalities should also be discarded, along with those for control municipalities with PSs lower than the minimum score for treatment municipalities; (See Appendix 2).

Once the model's assumptions have met, the impact estimator for the average treatment effect of the treated group (ATT) using Propensity Score Matching (PSM) would be:

of the PNCRT on the analysed variable (Heckman, 1998).

Appendix 1 lists the results of the probability model for which a logit model was initially estimated. It included variables related to population, conflict, and socioeconomic conditions that make a municipality likely to be a participant of policy intervention during the period before the treatment. In this case, the variables that had the major impact were those related to years of conflict, (historical violence) and social politics, such as the coverage by a subsidized health plan.

Once this estimate was made, it proceeded to review the pre-existence of possible differences between the treatment and control groups before treatment, as presented in Appendix 3. The results of the balance analysis revealed no significant differences between the municipalities selected by the PNCRT for treatment and the control municipalities that were statistically selected according to the established criteria. Additionally, the nearest neighbour matching method of estimation was

However, it should be noted that when comparing two similar municipalities, pre-existing differences could affect the evaluation results in some way. This is the case of municipalities for which some of the unobserved effects of the variables of interest persist over time. To complement the PSM method, the difference in differences model was then necessary to avoid any pre-existing differences that could affect the evaluation results.

\section{iii. Estimation strategy - The Difference in differences model}

The difference in differences model is commonly used in the analysis of quasi-experiments chosen because it decreases the estimated variance. 
because it brings efficiency through pre-existing conditions correction. Since it provides greater efficiency in the estimation, this method was applied in this study to correct pre-existing conditions between the control municipalities and the treatment municipalities. Logically, if the pre-existing difference had not been corrected, the estimate would have been partially endogenous (selection bias) and, therefore, the comparison of means between the control and treatment groups would not have been valid. Similarly, to implement this model, before conducting the evaluation, it was important to check the assumption of parallel trends. Hence, historical trends of each region of analysis were also reviewed. Annexe 4 shows the ones that shared similar behaviours.

The proposed model for the functional form regarding the PNCRT is Imbens \& Wooldridge (2007) model:

$$
Y=\mu+\lambda \cdot \mathrm{D}+\omega \cdot \mathrm{T}+\alpha(\mathrm{D} \cdot \mathrm{T})+\varepsilon
$$

* $Y$ is the outcome variable of interest for municipalities

* D is a Dummy variable that captures the possible differences between the treatment municipalities $(D=1)$ and control municipalities $(D=0)$

* $T$ is the Dummy variable that indicates the time when municipalities are observed and equals 1 for 2015, (the year when effects were examined).

- D.T. is an explanatory variable that is the result of multiplying the two variables; it captures aggregated factors that could cause changes in $Y$, even during the absence of the policy.

- $\lambda$ and $\omega$ represent parameters associated with explanatory variables $Y$ and $T$

* $\mu$ constitutes a parameter that shows fix effects of the model

* $\varepsilon$ shows a random error, of average 0 : $E[\varepsilon \mid D, T]=$ 0 .

* $\alpha$ is a coefficient of interest that determines the combined impact of variables or the interaction of explanatory variables $\mathrm{D}$ and $\mathrm{T}$.

\section{The Impact Assessment of Pncrt}

\section{a) Measurement of outcome variables}

The evaluation of the policy's effects examined the reestablishment of security in the regions intervened by the PNCRT, which is considered the absence of goaloriented violence vii due to internal armed conflict. As previously mentioned, according to the definition adopted by the U.N. in 2010, security implies the pacification of an area through a series of measures designed to reduce the risk of (peace) cessation, or of relapsing again into conflict by strengthening the conflict management capabilities of national organizations at all levels, and by laying the foundations for sustainable peace and development.
In the regions were PNCRT was implemented, the evaluation of the effects of the policy relies on the reestablishment of security, which is viewed as the absence of instrumental violence in the internal armed conflict. According to the United Nations definition, in 2010, the maintenance of security implies the territory pacification through a series of measures designed to reduce the risk of peace cessation or the relapsing again into conflict. This should be done by strengthening the conflict management capabilities of national organizations at all levels and by laying the foundations for sustainable peace and development.

However, in this sense, the concept of security depends on how this term is conceived by the government that implements the interventions and the outcome variables show the results of establishing

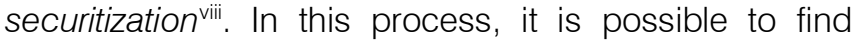
different meanings of the government's concept of security, which have been developed obliquely based on what it considers threats that must be addressed militarily.

In this sense and according to the government that implemented the PNCRT, there are three categories of threats to be considered. First, threats to human life and survival, which includes: targeted assassinations, specially of politicians, journalists or social leaders who oppose the violent actions of the armed forces; kidnappings, considered as the event in which a person is deprived of his liberty against his will at the hands of the Farc, the ELN, paramilitary groups or even common crime groups; forced disappearances, which may also be perpetrated by the same groups and even by State forces, according to Law 589 of 2000, it consists of the deprivation of liberty any persons in any form, followed by concealment and the refusal to acknowledge such deprivation. Other threats to human life and survival include sexual violence, defined by $\mathrm{DIH}$ as any act of a sexual nature against the will of the victim; recruitment of minors, that is children, adolescents, young people and adults who have been recruited to be part of the ranks of the insurgent group; displacement from homes, which occurs when individuals or families are forced to leave their homes because of armed group threat; antipersonnel mines, that is a war strategy sought to maintain control at the local level through the distribution of explosive mines in the territories and finally, massacres, defined as a group murder involving at least four deaths.

Second, threats that impact on property, such as military operations, victims of military operations, and damage to property. It is common that attacks perpetrated by insurgent groups, especially FARC or ELN, are carried out with the aim of damaging oil pipelines or electrical towers, destroying military posts, bridges or access roads to regions or any strategic communication points for economic development. (Cardenas, 2013, 26). Thirdly and last, illicit crops as 
measured by the number of hectares with coca crops by a municipality.

\section{b) PNCRT impacts}

Table 2 presents the effects of the PNCRT interventions and provides totals for the country as a whole and each analysed region. The first table section lists the impacts of the policy on threats to human life and survival. According to Cardenas, Eslava and Ramirez (2013) this events stress their effects on the civilian population, who has the feeling of being the direct target of the conflict. As can be seen in the table, without exception, all of the results for the variables of interest are negative values (Targetting Killing, Kidnapping, Desappearences, Recrutment of minors, Forced displace households, Antipersonel mines, Victims of antipersonel mines (average) and Massacres); this result shows the positive impact of the
PNCRT and the improvement of security in the treated municipalities. Unfortunately, and only the variables of disappearance and recruitment of minors are not statistically significant.

The nationwide results for the demining policy stand out, as it is fundamental for the process of land restitution to displaced peasants and to comply with the agreements at the 2010 Ottawa convention. Although the demining success is partly due to the support of civilian organizations, it should not be forgotten that, historically, this has been the strict purview of the military. This has created major obstacles for joint management of the demining process since two divergent perspectives are in play. On the one hand, it is the government that imbues the process with a national security perspective, and on the other hand, civilian organizations have a more humanistic perspective.

Table 2 : Regional Impacts of the National Policy for Territorial Consolidation and Reconstructiona

\begin{tabular}{|c|c|c|c|c|}
\hline Observable Characteristics & Total & $\begin{array}{c}\text { South } \\
\text { West } \\
\text { Region }\end{array}$ & $\begin{array}{l}\text { North-East } \\
\text { Region }\end{array}$ & $\begin{array}{c}\text { North } \\
\text { West } \\
\text { Region }\end{array}$ \\
\hline \multicolumn{5}{|l|}{ Threat to life and Human Survival } \\
\hline Targetting Killing & $-1,21^{\star}$ & $-1,85^{\star}$ & $-2,57^{\star \star}$ & $1,35^{\star}$ \\
\hline Kidnapping & $-0,49^{*}$ & $-0,54^{* *}$ & $-0,78$ & $-0,105$ \\
\hline Desappearences & $-0,54$ & 0,13 & 0,04 & $-1,30$ \\
\hline Recrutment of minors & $-0,81$ & $-2,22^{\star \star \star}$ & 0,128 & 0,46 \\
\hline Displace households & $-108,00^{*}$ & 38,03 & $-132,74^{\star}$ & $-246,44^{\star *}$ \\
\hline Antipersonel mines & $-5,27^{\star \star \star}$ & $-6,8^{\star \star}$ & $-4,91^{\star \star \star}$ & $-3,18^{\star}$ \\
\hline Victims of antipersonel mines (average) & $0,23^{\star \star *}$ & 0,07 & $0,81^{* \star \star}$ & 0,08 \\
\hline Massacres & $-0,09^{\star}$ & $-0,03$ & $-0,07^{\star}$ & 0,118 \\
\hline \multicolumn{5}{|l|}{$\begin{array}{c}\text { Attacks to public and private } \\
\text { infrastructure }\end{array}$} \\
\hline Military operations & $4,044^{\star \star \star}$ & $7,335^{\star \star \star}$ & $3,70^{\star}$ & 0,69 \\
\hline $\begin{array}{c}\text { Average number of victims of military } \\
\text { actions }\end{array}$ & $-0,49^{\star}$ & $-0,67^{\star \star}$ & 0,259 & $-0,97^{*}$ \\
\hline Damage to property & $-1,333^{* * *}$ & $-1,61^{*}$ & $-0,65$ & $-2,18^{\star \star \star}$ \\
\hline \multicolumn{5}{|l|}{ Eradication of illicit farming } \\
\hline Hectares of coca crops & $428,38^{*}$ & $839,30 *$ & $342,22^{*}$ & $-12,61$ \\
\hline
\end{tabular}

Difference is statistically significant at $10 \%$, at $5 \%$ ** at $1 \%$ ***

Source: created by the author

As we can see in the table, in general, results show there was an improvement regarding security in all regions. Results about the decrease of military actions in the south part of the country, that is the cessation of hostilities against oil and electrical industry are outstanding.
Concerning the first section, the threat to human survival and life, all variables showed a decrease in the threat, which contributed to the improvement of treatment municipalities. However, for disappearance and recruitment of minors, variables were not significant 
statistically speaking; that leads us not to ensure that the risk decreased.

On the other hand, results show progress in terms of the eradication of anti-personal mines. The findings in the south-west region evidence the importance of the land restitution to displaced peasants and the effort to accomplish what had been agreed during the Ottawa Convention in 2010.

The satisfactory outcomes in terms of antipersonal mines are a clear example of horizontal institutional coordination focused on a common objective, in which both civil and military organizations worked together and in a collaborative way. (Licha \& Molina, 2006, in Bulla y Guarin 2015,12). Incidentally, this task was not easy because both had divergent positions; civil organisations acted based on a humanistic approach whereas the military acted according to the national security policy. Anyway, the decrease of anti-personal mines brought excellent outcomes; no doubt it is also due to the information the guerilla group FARC provided about finding explosive devices since they were in peace talks with the state. It must be said, though that it is not so in the case of victims of mine explosions; despite the efforts of military, armed groups and civilian populations, the rate of these events only decreased slightly and results are unfortunately not significant in the municipalities. About displaced household, results show a significant decrease. Indeed, in the northwest region, formed by the departments of Antioquia, Bolivar, Cordoba and Sucre a larger number of two hundred families didn't suffer from rootlessness. Outcomes about displacement are a great step ahead considering that Colombia shows internal displacement rates that are comparable to those of Siria, Iran and the Republic of Congo.

Concerning targetting killing, findings were significant; they showed close to three fewer events on average for the Catatumbo and Arauca regions; almost two fewer cases for the southern region and slightly over one less for the northwest. According to the National Center of Historical Memory, this is one of the variables that most intimidate civilian populations since it not only concerns the victim but also creates physical, emotional and social coercion that leads to silence and thus to impunity.

Last but not least, concerning the outcome variables of kidnapping and sexual violence, the rate diminished considerably. However, though results are significant, they are not conclusive because according to the method Differences-in-differences, based on the analysis of parallel trends, these variables presented a dissimilar behaviour before policy intervention (see appendix 4).

The second section of Table 2 presents results that showed a decline in hostilities and infrastructure damage for the south part of the country in terms of bombings of oil pipelines and military operations. According to Pecaut (2002), attacks on infrastructure are part of a political strategy to impact security. In this sense, results were highly significant because they not only showed seven fewer military operations, that could have compromised electricity towers of Tumaco, but also had a national impact, with an average reduction of more than four events (at 99.9\% average level of significance), for the country as a whole.

Lastly, the third section reveals the effects of the policy on the eradication of illicit farming. The increase in hectares planted with coca is the worst outcome in terms of the PNCRT's objectives. In general terms, it can be attributed to two circumstances: on the one hand, the planting of herbicide-resistant coca varieties called la cuarentona and la gringa; on the second hand, the fact that coca planting is highly concentrated in border regions since glyphosate fumigation is prohibited. In fact, between 2008 and 2018, the government of Colombia had to face a lawsuit before the International Justice Court in la Hague for damage caused by the aspersion of this herbicide. This is consistent with the fact that illicit farming has increased in the southwest region by more than eight hundred hectares on average, especially in the municipality of Tumaco, on the Ecuatorian border and in the department of Putumayo, which borders Ecuador and Peru in the Amazon rain forest. Similarly, coca cultivation increased significantly by more than three hundred hectares on average in the northeast region as it is located along the border with Venezuela.

On the other hand, Bulla and Guarin, (2015) have pointed out endemic elements present in municipalities like Tumaco in the southwest part of the country. This municipality is characterized by a state institutionality that doesn't reach the whole municipality and then leaves the rest of it in hands of armed organizations such as the FARC and criminal groups. Accessing these isolated territories, mostly made up of dispersed rural population, is a major difficulty, mobility costs can even reach US 40 per trip. Logically, since they are isolated and under the protection of armed and criminal groups, inhabitants of these territories contribute to the illicit activities that have been set. Furthermore, this suggests that the economic impact of institutional strengthening is not economic, while the profits from illicit crops continue to be profitable in this area. This is corroborated by the results pointed out by Aguirre (2020) where it is evident that after the intervention, the fiscal collection in terms of Industry and Commerce barely grew by less than $1 \%$, in this part of the territory.

In contrast, the results shown in the northwest region, illicit crops have been reduced. At first glance, they seem to be satisfactory; however, it should be noted that according to data from the Ministry of Mines 
and Energy, this part of the country produces a third of Colombia's gold. Of course, illicit mining generates greater benefits than illicit crops. Yet, this activity is the survival source for the inhabitants of the lower Cauca Antioqueño and unfortunately, the armed groups ensure their exploitation by contractual arrangements or the use of force and extortion. (Giraldo et al, 2010; Mc Dermott, 2013). In other words, what for Collier (2000) or Kalyvas (2006) corresponds to a transformation of the use of resources by armed groups, which find a better comparative advantage in gold extraction and in relation to illicit crops. In this same line of argument, the socalled lootable resources of Findley and Marineau (2015) are represented by gold, in the Northwest of the country.

\section{Conclusions}

Throughout its history, the governments of Colombia have had several initiatives to implement actions to guarantee peace in conflict zones. In fact, since the government of former ex-president Carlos Lleras (1958-1962), many administrations have tried to implement peace programs and negotiations with insurgent groups. Recently, during the mandate of former ex-president Juan Manuel Santos (2004-2008), the National Policy for Territorial Consolidation and Reconstruction (PNCRT) was implemented to ensure the irreversibility of security gains and strengthen the state's presence in territories devastated by decades of violence.

This study aimed to assess the impact on security of the National Policy of Territorial Consolidation and reconstruction (PNCRT) in the conflict territories between 2010 and 2014. It analysed the findings in the regions that were selected by the policy, that is, the north-west region (Montes de Maria and Nudo de Paramillo), the northeast region (Catatumbo and Arauca) and the southwest region (Cauca, Tumaco, Macarena, El Caguán, Tumaco and the Central Mountain range).

Research process required comparing the municipalities affected by the policy with other municipalities that share identical characteristics. It was the Propensity Score Matching method that allowed us to do this. In addition, to evaluate the impacts of the policy in terms of threats to security, threats to human life and survival, attacks on public and private infrastructure and the eradication of illicit crops, this study used the Difference in Difference technique.

In general, after the intervention of the policy in the three zones, the analysis of outcomes showed a decrease concerning attacks against public infrastructure and threats to life and human survival. (Kidnapping, targetting killing, displaced household, anti-personal-mines, victims of them, massacres, disappearance, sexual violence and recruitment of minors. Indeed, Salas (2016) mentions that 2015 was, in fact, the year when there was the lowest percentage of violence.

The results relating to the impact of the antipersonnel mine policy should be highlighted, as it was the policy's greatest of institutional coordination achievement, bringing civil organizations together to help rural populations. In this sense, the government's strategy succeeded in involving civil society to achieve a stable and lasting peace.

The evaluation of the implementation of the PNCRT shows significant progress in terms of civil security and respect for life and dignity. It also shows signs of a recovery of political control of the conflict zones, in view of the mitigation of attacks on infrastructure. At the same time, the PNCRT does not fully achieve its objectives, in terms of reducing drug trafficking, its efforts are still incipient. Apparently, achieving institutional strengthening is not unthinkable; that would mean being able to reach the most remote rural areas of the country historically governed by their competitors, controlling the spread of illegal activities and presenting more profitable rural economic alternatives, like a National Rural Guard suggested by the Bulla y Guarin, (2015)

On the other hand, it is interesting to note that the Northwest region, where the results showed the lowest number of displaced households, coincides with the only region where no increase in illicit crops was found; in this sense, it is possible to affirm that there is a direct relationship between the expansion of illicit crops and forced displacement. However, this would be a subject of study for further research.

On the contrary, the policy did not go very far in eradicating illicit crops. The results showed a disproportionate increase in coca plantations in the study regions, except for the northwest region; there the decrease in coca leaf cultivation is evident but, unfortunately, the labour force from these crops shifted towards activity related to illicit mining. This result shows that illegality represents the most lucrative economic alternative for thousands of families and armed groups in the conflict regions. Therefore, in the future, policies that promote the eradication of illicit crops must ensure economic alternatives that can guarantee returns above those left by illicit activities. Adittionally, the ineffectiveness of politics in this sense is a huge warning signal to state institutions and the peace building. As the Centre for Historical Memory has already pointed out, drug trafficking allows for the financing of armed groups, deepens inequality in the countryside because thousands of families are displaced by the growers or threatened to sell part of their land at a lower price, and increases corruption at the local level. 


\section{ACKNOWLEDGEMENTS}

The author is grateful to financial support at the Universitaria Agustiniana for the consecution of this paper.

\section{References Références Referencias}

1. Acemoglu, D., García-Jimeno, C., and Robinson, J. 2015 "State Capacity and economic development; A network approach" American Economic Review 105 (8). 2364-2409. https://doi.org/10.1257/ae r.20140044

2. Acemoglu, D., Ticchi, D., and Vindigni, A. 2011 "Emergence and Persistence of Inefficient States" Journal of the European Economic Association 9, (2) 177-208. https://doi.org/10.3386/w12748

3. Aguirre-Muñoz, B. A. 2020 "Efectos de la Política Nacional de Consolidación y Reconstrucción Territorial en la economía de las regiones en conflicto de Colombia". Estudios Gerenciales, 36(155), 193-205. https://doi.org/10.18046/j.estger. 2020.155.3343

4. Balthasar, D., 2017 "Peace-building as statebuilding'? Rethinking liberal interventionism in contexts of emerging states" Conflict, Security \& Development, 17 (6) 473-491, https://doi.org/1 0.1080/14678802.2017.1406180

5. Barham, E., and Kleinfield, R. 2018 "Complicit States and the Governing Strategy of Privilege Violence: When Weakness is Not the Problem" Annual Review of Political Science 21. 215-238. http s://doi.org/10.1146/annurev-polisci-041916-015628

6. Bates, R. 2001 "Prosperity and Violence: The Political Economy of Development" New York: W.W. Norton \& Co.

7. Bayart, Jean-Francois. 1993 "The State in Africa: The Politics of the Belly" Longman, New York.

8. Bernal, R., and Peña, J. 2011 "Guía práctica para la evaluación de impacto" Bogotá: Ediciones Uniandes.

9. Besley, T., and Torsten, P. 2009 "The Origins of State Capacity: Property Rights, Taxation, and Politics" American Economic Review 99 (4).12181244. https://doi.org/10.1257/aer.99.4.1218

10. Böge, V., Brown, A., Clements K., and Nolan, A. 2008 "On Hybrid Political Orders and Emerging States: State Formation in the Context of Fragility" Berghof Research Centre, Berlin.

11. Boone, C. 2012 "Territorial politcs and the reach of the State: Unevenness by design" Revista de ciencia política (Santiago) 32 (3). 623-641. ISSN 0718-090X. http://dx.doi.org/10.4067/S0718090X2012000300007.

12. Bulla, $P$ and Guarín, S. 2015 "Rural Security in Colombia: An Opportunity for State Consolidation" Stability: International Journal of Security \&
Development, 4(1): 37, pp.1-19, DOI: http://dx.doi .org/10.5334/sta.ga

13. Buzan, B., Wver Ole, Wæver, O., and De Wilde, J. 1998 "Security: A new framework for analysis" Boulder: Lynne Rienner.

14. Caliendo, M., and Kopeinig, S. 2008 "Some practical guidance for the implementation of propensity score matching" Journal of Economic Surveys 22 (1). 31-72.

15. Cansino, J., and Braza, A. 2006 "Cálculo del estimador de diferencias en diferencias aplicado a la evaluación de programas públicos de formación: métodos alternativos para su obtención a partir de datos simulados" Almería, España. ISBN 84-8240795-3.

16. Cárdenas, M., Eslava, M., and Ramírez S. 2016 "Why internal conflict deteriorates state capacity? Evidence from colombian municipalities" Defence and Peace Economics 27 (3). 353-377. https://doi.org/10.1080/10242694.2014.955668

17. Centeno, M. 2002 "Blood and Debt: War and the Nation-State Latin America" University Park: Penn State University Press.

18. Centro Nacional de Memoria Histórica (CNMH) 2013 "iBasta ya! Colombia: memorias de guerra y dignidad" Bogotá. Imprenta Nacional.

19. Chernick, M. 1996 "Aprender del pasado: Breve historia de los procesos de Paz en Colombia (19821996)" Edición Especial: Seminario sobre procesos de negociación y Paz. Departamento de Ciencias Políticas. Bogotá: Universidad de los Andes, https://doi.org/10.7440/colombiaint36.1996.02

20. Chernick, M. 1999 "Negotiating Peace amid Multiple Forms of Violence: The Protracted Search for a Settlement to the Armed conflicts in Colombia" In Comparative Peace Processes in Latin America, edited by C. Arnson, 159-196. Washington, DC: Woodrow Wilson Center

21. Cuadros, F. 2016 "Análisis de la Política Nacional de Consolidación y Reconstrucción Territorial PNCRT implementado en Putumayo en el periodo 2011 - 2015" MSc. Universidad Javeriana.

22. Departamento Administrativo Nacional de Estadística -DANE. Series de población 1985-2020. Colombia. Estimaciones 1985-2005 y Proyecciones 2005-2020 nacional y departamental desagregadas por sexo, área y grupos quinquenales de edad. Accesed May 5, 2020. https://www.dane.g ov.co/index.php/estadisticas-por-tema/demografiay-poblacion/series-de-poblacion.

23. Departamento Nacional de Planeación. 2020 "Informe de progreso del plan nacional de rehabilitación (Conpes 2090)", Bogotá. Accesed May 5, 2020 https://colaboracion.dnp.g ov.co/CDT/Conpes/Econ\%C3\%B3micos/2090.pdf

24. Departamento Nacional de Planeación. Plan Nacional de Desarrollo 2002-2006: Hacia un Estado 
Comunitario (29-98). Accesed May 5, 2020 https://colaboracion.dnp.gov.co/cdt/pnd/pnd.pdf

25. Duarte, N., Espinosa Jose E, García, M., Revelo J., and Torres N. 2017 "Los territorios de la paz. La construcción del Estado local en Colombia. Bogotá" Centro de estudios de derecho, justicia y Sociedad, Dejusticia. Accesed 5 May 2020: https:// www.dejusticia.org/publication/los-territorios-de-la-p az-la-construccion-del-estado-local-en-colombia-2/

26. Gertler. P., Martínez S., Premand, P., Rawlings, L, and Vermeersch Ch. 2011 "Impact Evaluation in Practice" The International Bank for Reconstruction and Development. The World Bank.

27. Giraldo, J., Barón, M., Duncan, G., Jaramillo, A.M. \& Naranjo, A. 2010 "Economía criminal en Antioquia y Valle de Aburrá: una aproximación" Universidad EAFIT y Proantioquia. Recuperado el 11 de febrero de 2015 en: http://www.ideaspaz.org/tools/d ownload/52148

28. González, F., 2014 "Poder y Violencia en Colombia”. Bogotá, D.C, Colombia: Cinep- Odecofi. ISBN: 978-958-644-171-1

29. González, F., I. Bolívar, and T. Vásquez. 2003 "Violencia política en Colombia: de la nación fragmentada a la construcción del Estado". Bogotá: Cinep-PPP.

30. Green, P., and Ward, T. 2009 "State-Building and the Logic of Violence in Iraq" Journal of Scandinavian Studies in Criminology and Crime Prevention, $10 \quad$ (1). 48-58. https://doi.or $\mathrm{g} / 10.1080 / 14043850903316212$

31. Heckman, J., Ichimura, H., and Todd, P. 1998 "Matching as an econometric evaluation estimator:Evidence from evaluating a job training programme" Review of Economic Studies 65. 261294. https://doi.org/10.2307/2971733

32. Herbst, J. 2000 "States and Power in Africa: Comparative Lessons in Authority and Control" Princeton: Princeton University Press.

33. Imbens, W. and Jeffrey M. 2009 "Recent developments in the econometrics of program evaluation" Journal of Economic Literature 47 (1). 586.

34. Jackson, R. 1990 "Quasi-States: Sovereignty, International Relations and the Third World" Cambridge University Press, Cambridge.

35. Licha, I. \& Molina, C. G. 2006 "Coordinación de la política social: Criterios para avanzar" Instituto Interamericano para el Desarrollo Social: Documento de trabajo. Recuperado el 2 de julio de 2020 en: http://idbdocs.iadb.org/wsdocs/getdoc ument.aspx?docnum $=2220392$

36. López, C. 2016 "iAdios a las Farc!. ¿Y ahora qué?" Bogotá - Colombia: Penguin Random House grupo Editorial. S.A.S.
37. McDermott, J. (2013, 20 de mayo). "Bloque Iván Ríos: La división de combates más vulnerable de las FARC" InSight Crime. Recuperado el 1 de febrero de 2015 en: http://es.insightcrime.org/ pazFARC/bloque-ivan-rios-division-combate-vulnra ble-FARC

38. Mann, M. 1993 "The Sources of Social Power. Volume II: The Rise of Classes and Nation-States" 1760-1914. New York: Cambridge University Press

39. Pécaut, D. 2002 "Hacia la desterritorialización de la guerra y de la resistencia civil". Ponencia presentada en el Seminario Internacional Dimensiones Territoriales de la Guerra y la Paz. Bogotá: Universidad Nacional de Colombia, Red de Estudios de Espacio y Territorio.

40. Rojas, D. 2007 "Plan Colombia II: ¿más de lo mismo?" Colombia internacional 65. 14-37.ISSN 0121-5612

41. Salas-Salazar, L. 2016 "Conflicto armado y configuración territorial: elementos para la consolidación de la paz en Colombia" Bitacora 26 (2). 45-57 doi:http://dx.doi.org/10.15446/bitaco ra.v26n2.57605

42. Tilly, Ch. 1990 "Coercion, Capital and European States AD 900-1990" Cambridge MA: Basil Blackwell.

43. Torres, O. 2015 "Difference in differences (DID) Estimation step-by-step" Universidad de Princeton.

44. Unidad para la atención y reparación integral a las Víctimas- UARIV. Publicación de datos abiertos. Reporte de víctimas por hecho victimizante. Accesed May 5 2020: https://www.unidadvictimas .gov.co/es/planeacion-y-seguimiento/publicacionde-datos-abiertos/161

45. United Nations 2010 "UN Peacebuilding: An Orientation" United Nations, New York.

46. Vargas, R. 2005 "Cultivos ilícitos en Colombia: elementos para un balance" Fundación seguridad y democracia. Bogotá. Accesed May 5, 2020: http://www.mamacoca.org/docs de base/Fumigas/ VargasRicardo_Elementos_para_un_balance_2005. pdf

47. Villarraga, A. 2015 "Biblioteca de la Paz 1980-2013: Los procesos de paz en Colombia, 1982-2014 (Documento resumen)" Bogotá, Colombia: Fundación Cultura Democrática

48. Wade, Robert H. 1990 "Governing the Market" Princeton: Princeton University Press.

49. Zartman, W. (ed. 1995) "Collapsed States: The Disintegration and Restoration of Legitimate Authority" Lynne Rienner, Boulder, CO. 
Appendix 1: Probability model.

\section{APPENDICES}

\begin{tabular}{|c|c|c|c|c|}
\hline Variables & Estimated & SE & $Z$ value & $P$ value \\
\hline Population density & -0.002881 & 0.003973 & -0.725 & 0.46836 \\
\hline Recruitment & 0.127442 & 0.081774 & 1.558 & 0.11912 \\
\hline Illicit crops & $166,680,831$ & $95,485,823$ & 1.746 & 0.08088 * \\
\hline Targeted assassinations & 0.360332 & 0.142946 & 2.521 & 0.01171 * \\
\hline Victims of military operations & 0.159378 & 0.143626 & 1.110 & 0.26714 \\
\hline Damage to property & 0.233689 & 0.108403 & 2.156 & 0.03110 * \\
\hline Kidnappings & 0.201546 & 0.098059 & 2.055 & 0.03984 * \\
\hline Attacks on the civilian population & 0.404439 & 0.394127 & 1.026 & 0.30481 \\
\hline Massacres & 0.550517 & 0.248571 & 2.215 & 0.02678 * \\
\hline Infant mortality & -0.023167 & 0.029185 & -0.794 & 0.42731 \\
\hline Participation in previous policies & $3,299,680$ & 0.529328 & 6.234 & $4.55 \mathrm{e}-10 * * *$ \\
\hline Subsidized health care coverage & $-2,983,953$ & $1,469,414$ & -2.031 & 0.04228 * \\
\hline Aqueduct (running water) coverage & 0.011434 & 0.010379 & 1.102 & 0.27063 \\
\hline Garbage collection coverage & 0.004079 & 0.014545 & 0.280 & 0.77914 \\
\hline Sewer system coverage & -0.012038 & 0.014294 & -0.842 & 0.39968 \\
\hline Fiscal dependency & $-1,870,447$ & $1,124.653$ & -1.663 & $0.09629 *$ \\
\hline Sexual violence & -0.272454 & 0.097969 & -2.781 & 0.00542 ** \\
\hline Per capita royalties & -0.195578 & 0.893456 & -0.219 & 0.82673 \\
\hline Total tax revenue & $-5,586,407$ & $7,971,187$ & -0.701 & 0.48341 \\
\hline Property tax revenue & $-27,613,642$ & $17,173,687$ & -1.608 & 0.10786 \\
\hline Industry/commerce (ICA) tax revenue & $7,159,766$ & $9,408,764$ & 0.761 & 0.44668 \\
\hline Percentage of Voters & $-7,207,827$ & $5,967,211$ & -1.208 & 0.22708 \\
\hline
\end{tabular}

Appendix 2- Common support probability charts

Common support without replacement

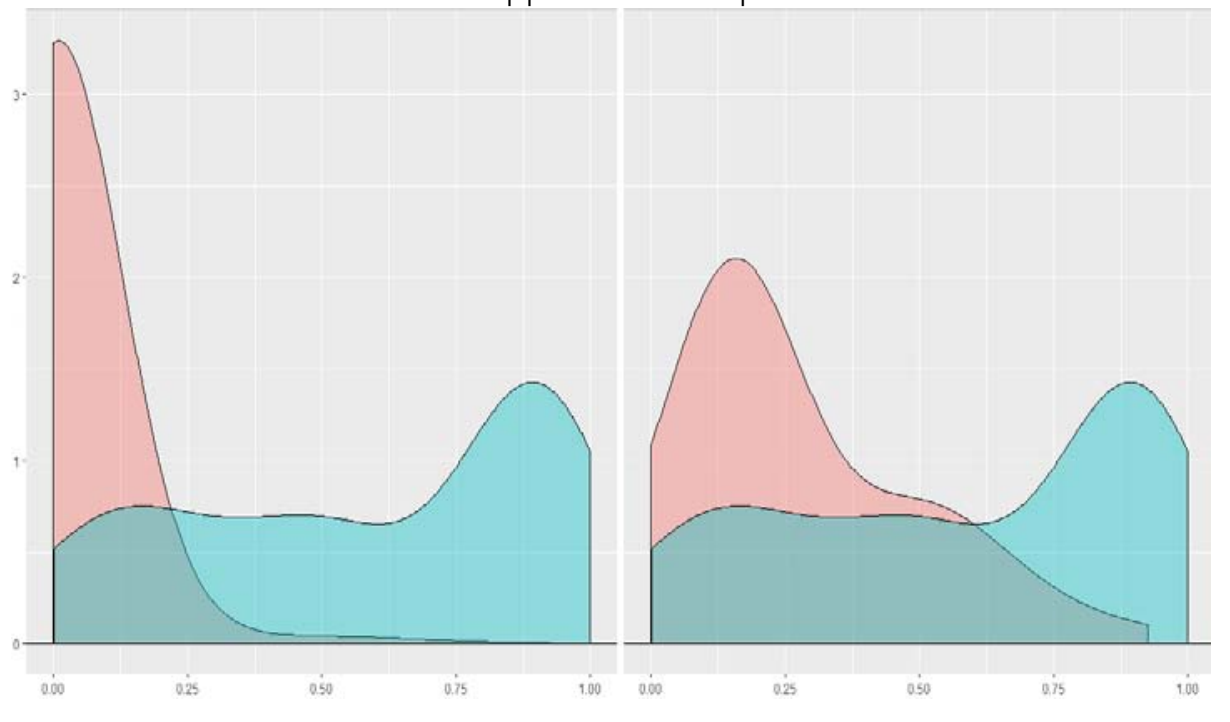


Common support with replacement

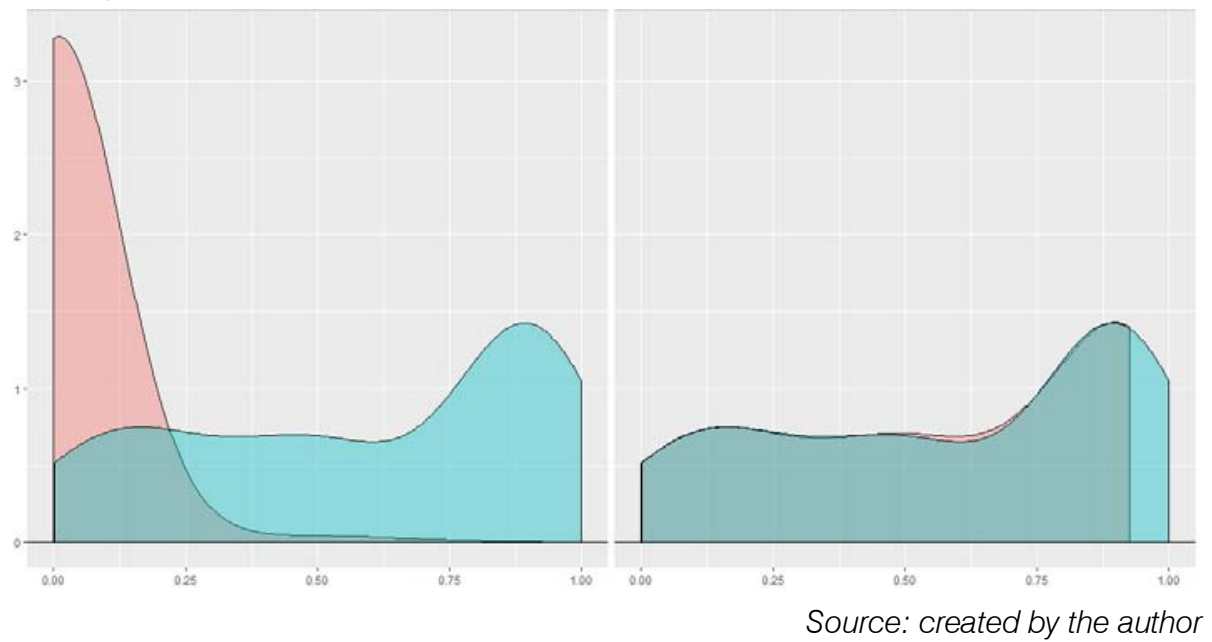

Appendix 3- Differences between the treatment and control municipalities prior to policy intervention. Balance analysis for sociodemographic characteristics

\begin{tabular}{|c|c|c|c|}
\hline \multirow{3}{*}{$\begin{array}{c}\text { Characteristics observed in the } \\
\text { municipalities }\end{array}$} & \multirow{3}{*}{$\begin{array}{c}\text { Treated } \\
\text { municipalities }\end{array}$} & \multicolumn{2}{|c|}{ Technique used } \\
\hline & & Without replacement & With replacement \\
\hline & & Control & Control \\
\hline \multicolumn{4}{|c|}{ Sociodemographic characteristics } \\
\hline \multirow{2}{*}{ Population density } & 35.78 & 48.85 & 44.30 \\
\hline & & $(74.86)$ & $(77.02)$ \\
\hline \multirow{2}{*}{ Subsidized health care coverage } & 0.87 & 0.89 & 0.86 \\
\hline & & $(0.14)$ & $(0.13)$ \\
\hline \multirow{2}{*}{ Aqueduct (running water) coverage } & 47.31 & 60.47 & 46.67 \\
\hline & & (32.79) & (28.62) \\
\hline \multirow{2}{*}{ Sewer system coverage } & 36.38 & 44.89 & 31.58 \\
\hline & & (34.01) & $(27.35)$ \\
\hline \multirow{2}{*}{ Garbage collection coverage } & 44.33 & 50.68 & 40.92 \\
\hline & & $(33.05)$ & $(27.55)$ \\
\hline \multirow{2}{*}{ Infant mortality rate } & 25.09 & 23.56 & 23.97 \\
\hline & & $(8.43)$ & $(7.73)$ \\
\hline \multirow{2}{*}{ Percentage of voters } & 0.53 & 0.54 & 0.52 \\
\hline & & $(0.04)$ & $(0.05)$ \\
\hline \multicolumn{4}{|c|}{ Conflict-related characteristics } \\
\hline \multirow{2}{*}{$\begin{array}{l}\text { Recruitment (total for the period } \\
\text { 1999-2010) }\end{array}$} & 7.01 & 5.79 & 5.30 \\
\hline & & $(3.41)$ & (2.33) \\
\hline \multirow{2}{*}{$\begin{array}{c}\text { Targeted assassinations (total for the } \\
\text { period 1999-2010) }\end{array}$} & 11.96 & 11.74 & 11.66 \\
\hline & & $(1.91)$ & $(1.87)$ \\
\hline \multirow{2}{*}{ Participation in Plan Colombia } & 0.64 & 0.33 & 0.62 \\
\hline & & $(0.47)$ & $(0.49)$ \\
\hline \multirow{2}{*}{ Attacks on civilians } & 0.37 & 0.40 & 0.27 \\
\hline & & $(0.61)$ & $(0.52)$ \\
\hline \multirow{2}{*}{ Victims of military operations } & 1.42 & 0.94 & 0.51 \\
\hline & & $(1.44)$ & $(1.31)$ \\
\hline \multirow{2}{*}{ Damage to property } & 1.88 & 1.05 & 1.40 \\
\hline & & (2.16) & (1.49) \\
\hline \multirow{2}{*}{$\begin{array}{l}\text { Kidnappings (average for the period } \\
1999-2010)\end{array}$} & 9.50 & 8.81 & 9.37 \\
\hline & & $(2.67)$ & $(2.53)$ \\
\hline \multirow{2}{*}{ Massacres } & 1.71 & 1.55 & 1.53 \\
\hline & & $(0.91)$ & $(0.62)$ \\
\hline Sexual violence (total for the period & 7.70 & 6.90 & 7.57 \\
\hline
\end{tabular}




\begin{tabular}{|c|c|c|c|}
\hline 1999-2010) & & $(3.83)$ & $(3.45)$ \\
\hline \multirow{2}{*}{$\begin{array}{l}\text { Percentage of hectares of coca } \\
\text { crops }\end{array}$} & 0.00 & 0.00 & 0.00 \\
\hline & & $(0.002)$ & $(0.00)$ \\
\hline \multicolumn{4}{|c|}{ Tax revenue characteristics } \\
\hline \multirow{2}{*}{ Fiscal dependency } & 0.80 & 0.81 & 0.59 \\
\hline & & $(0.21)$ & $(0.27)$ \\
\hline \multirow{2}{*}{ Per capita royalties } & 0.08 & 0.04 & 0.15 \\
\hline & & $(0.09)$ & $(0.16)$ \\
\hline \multirow{2}{*}{ Per capita tax revenue } & 0.08 & 0.09 & 0.09 \\
\hline & & $(0.14)$ & $(0.05)$ \\
\hline \multirow{2}{*}{ Per capita property tax revenue } & 0.01 & 0.01 & 0.01 \\
\hline & & $(0.01)$ & $(0.01)$ \\
\hline \multirow{2}{*}{$\begin{array}{l}\text { Per capita industry and commerce } \\
\text { tax revenue }\end{array}$} & 0.02 & 0.03 & 0.04 \\
\hline & & $(0.11)$ & $(0.03)$ \\
\hline
\end{tabular}

Note: the figures for each variable are averages and the standard deviation is indicated below in parentheses.

Source: created by the author

Appendix 4- Parallel trend charts

Targeted assassinations (1990-2009)- Total national

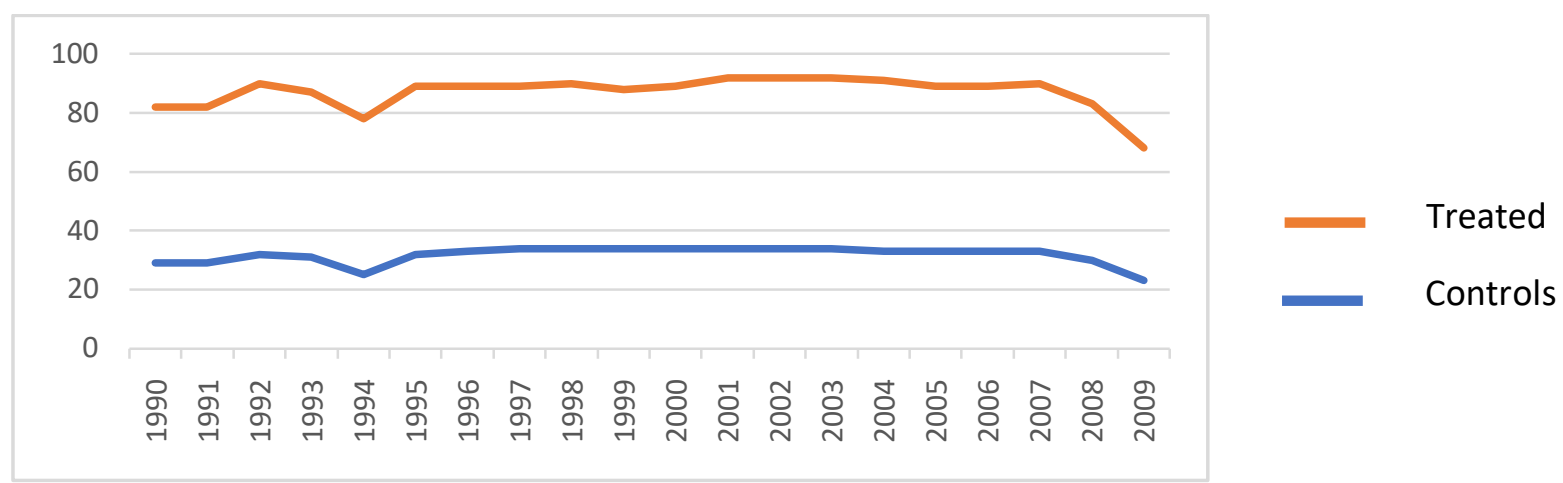

Targeted assassinations (1990-2009) Southwest

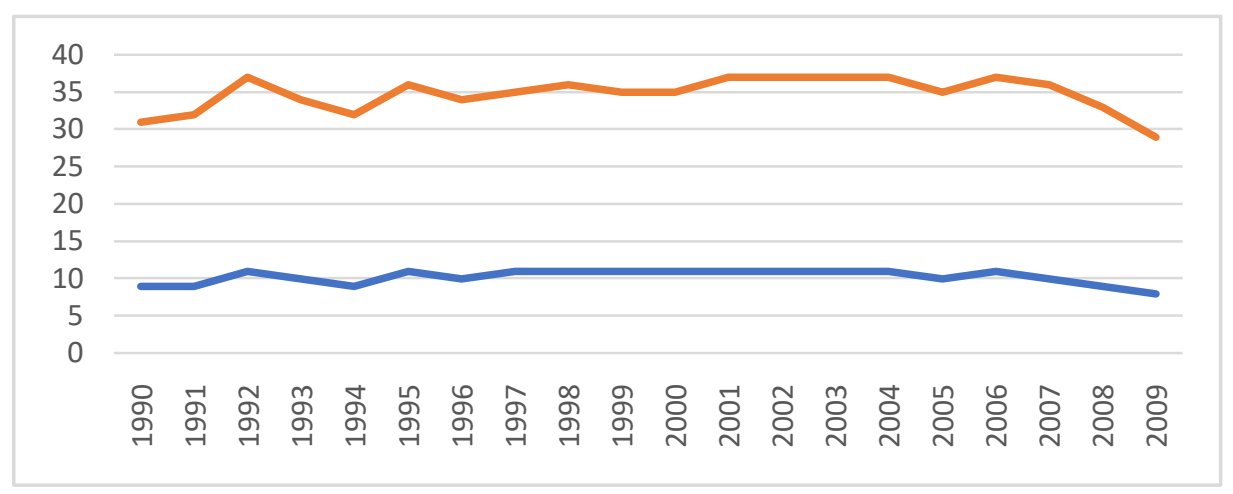


Notes

Targeted assassinations (1990-2009) North-east

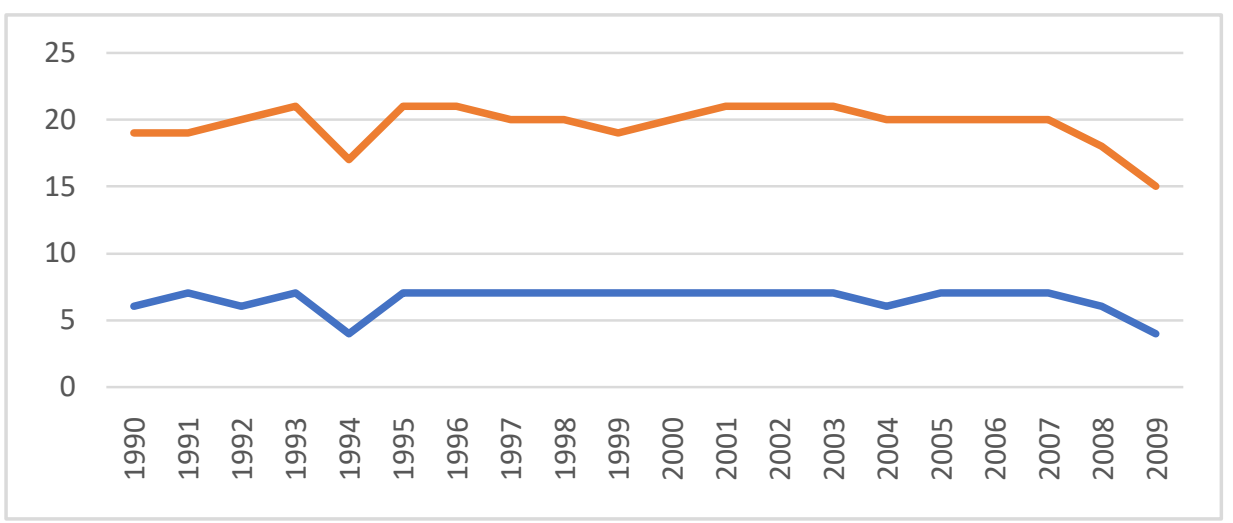

i. Possibility conditions refer to what Pierre Bourdieu considers the relational terms in which the work of individuals within a specific field unfolds and how these conditions are reproduced, for example, the actions or things that are recognized in a given context and the mechanisms involved in acquiring or losing it.

ii. Unidad Administrativa para Consolidación Territorial: Política Nacional de Consolidación y Reconstrucción Territorial. [Online publication] Available at http://www.consolidacion.gov.co/?q=content/pol\%C3\%ADticanacional-de-consolidaci\%C3\%B3n-y-reconstrucci\%C3\%B3n-territorial [accessed June 17, 2019]

iii. Article 26 of the National Development Plan 2010-2014, the Congress of the Republic in 2011 determined that the strategic direction of the PNCRT would be the responsibility of the National Security Council

iv. The areas to start the consolidation were the Macarena and Caguan River Zone, Pacific Zone (Nariño, Cauca, Buenaventura, South Choco), Lower Cauca Antioquia and South Cordoba Zone, South Tolima and South Valle del Cauca. The transition areas were the Montes de Maria Zone, the Sierra Nevada de Santa Marta Zone and the Eastern Antioquia Zone. And finally, the complementary areas were the Arauca Zone, Putumayo Zone, Catatumbo Zone and Bajo Atrato Zone (Presidency of the Republic, 2009).

v. Main text. Política Nacional de Consolidación y Reconstrucción Territorial (National Policy for Territorial Consolidation and Reconstruction). Version 1- 2012; page 6.

vi. This method assumes that unobservable or unavailable variables are not determining factors in the participation of the policy.

vii. This is understood as violence for the purpose of eliminating, intimidating, or provoking an opponent. Green P., and Ward T., State-Building and the Logic of Violence in Iraq; page 49.

viii. According to Barry Buzan and Ole Wæver, the action of promoting or creating security is the discursive process through which an intersubjective understanding is developed within a political community to treat something like an existing threat towards a valued object, and to enable urgent and exceptional measures to deal with the threat. Therefore, some variables should be viewed as humanitarian issues, such as antipersonnel mines, and variables such as hectares of coca crops that are more of an economic issue than a national security one but that are considered by the policy to be a security problem. 